\title{
The beta cell lesion in type 2 diabetes: there has to be a primary functional abnormality
}

\author{
S. E. Kahn • S. Zraika • K. M. Utzschneider • R. L. Hull
}

Received: 12 January 2009 / Accepted: 10 February 2009/Published online: 27 March 2009

(C) Springer-Verlag 2009

\begin{abstract}
The critical role of the beta cell in the pathogenesis of type 2 diabetes is now well established. When examined in patients with type 2 diabetes and individuals at increased risk, reductions in beta cell mass and abnormalities of beta cell function can both be demonstrated. The question of whether one alone is sufficient or both are necessary for the development of hyperglycaemia has been debated. Based on human and animal studies, it appears that neither alone is sufficient. Rather, for glucose to rise to the level at which diabetes would be diagnosed, defects in beta cell mass and in beta cell function are required.
\end{abstract}

Keywords Amyloid - Animal models - Beta cell function . Beta cell mass · Beta cell volume - Genes · Glucagon · Insulin secretion $\cdot$ Islets $\cdot$ Pancreatectomy

\section{Abbreviations \\ GLP-1 Glucagon-like peptide-1 \\ IAPP Islet amyloid polypeptide \\ IGT Impaired glucose tolerance}

\section{Introduction}

Science frequently resembles a pendulum. We learn, we forget, we relearn. Put another way, new tools frequently allow us to rediscover principles that were already known, sometimes quite well known. Type 2 diabetes represents the perfect example.

S. E. Kahn $(\bowtie) \cdot$ S. Zraika $\cdot$ K. M. Utzschneider $\cdot$ R. L. Hull Division of Metabolism, Endocrinology and Nutrition,

Department of Medicine,

VA Puget Sound Health Care System (151),

1660 S. Columbian Way,

Seattle, WA 98108, USA

e-mail: skahn@u.washington.edu
Consider the divide between insulin resistance and beta cell dysfunction. These two factors are both critically important in the pathogenesis of the hyperglycaemia of type 2 diabetes. However, the focus on each is such that one would never believe that both were critical players, but rather the onset of diabetes was simply due to one or the other. Certainly, only about 15 years ago, a visit to many diabetes research centres or clinics in the USA would have left you convinced that insulin resistance was the only important player [1]. The beta cell and its maladies were viewed as a late occurrence and of little import. Nowadays, on both sides of the Atlantic and in most regions of the world, the critical nature and early occurrence of beta cell abnormalities is no longer in question [2]

When one digs a little deeper into the saga of the beta cell, one discovers another debate. Is it mass or is it function that is important? Does reduced mass explain reduced function? Can an individual develop the disease with one and not the other? Again there is an element of polarisation. In this perspective we examine this issue in a little more detail and come to the conclusion that no beta cell biologist has to be wrong. Rather, the consensus should be that both, and indeed several aetiologies may exist and are critical in the demise of the beta cell in type 2 diabetes.

\section{Is beta cell mass reduced in type 2 diabetes?}

It has been known for more than a century that islets of individuals with type 2 diabetes have morphological abnormalities. In fact, in 1901 Opie published hand-drawn colour images of haematoxylin and eosin staining clearly demonstrating decreased cellularity and the presence of hyaline material in the islets of Langerhans [3] (Fig. 1). This was subsequently followed by papers from McLean 


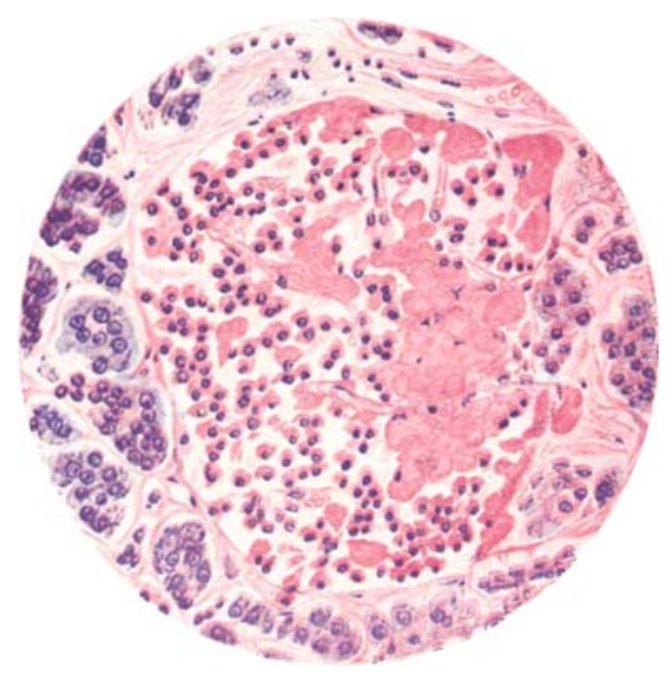

Fig. 1 Hand-drawn micrograph of an islet from a patient with type 2 diabetes. Staining was with haematoxylin and eosin. Cellularity of the islet is decreased and it contains eosinophilic material, then termed hyalinosis and nowadays known as amyloid. Reprinted with permission [3]

and Ogilvie [4] as well as Klöppel et al. [5] demonstrating that the volume of beta cells was reduced in type 2 diabetes (Fig. 2a,b). Interestingly, alpha cell mass was not decreased, resulting in a relative increase in the alpha:beta cell ratio [4]. More recently, Butler et al [6] confirmed these findings and extended them by showing that beta cell volume is decreased in patients with impaired fasting glucose to a degree intermediate between normal and diabetes (Fig. 2c). The exact degree of beta cell reduction remains somewhat unclear and possibly even controversial. Studies by a number of investigators suggest that it is between $0 \%$ and $63 \%$ [5-11]; however, we believe that recent work by Rahier and colleagues [12] represents the best assessment. The reason for believing so is that this work includes sampling in over 100 individuals from both the body and tail of the pancreas, two regions which vary with respect to how much of the islet is comprised of beta cells, with the tail known to contain greater amounts. This comprehensive study places the loss of beta cells at under $40 \%$, occurring similarly in islets in the body and tail of the pancreas [12] (Fig. 3). Further, this reduction occurred similarly in patients who were normal weight (BMI $<25 \mathrm{~kg} / \mathrm{m}^{2}$ ) or overweight/ obese (BMI $26-40 \mathrm{~kg} / \mathrm{m}^{2}$ ) and was only $24 \%$ in patients who had been diagnosed up to 5 years previously, compared with $54 \%$ in patients with disease duration in excess of 15 years.

If beta cell mass is reduced, can this be the sole explanation for the development of hyperglycaemia in type 2 diabetes? To answer this, studies in humans and animals can provide a better understanding. Hemi-pancreatectomy in human donors fails to produce frank hyperglycaemia. In first-degree relatives of the recipient, no significant change in fasting glucose and a small change in intravenous
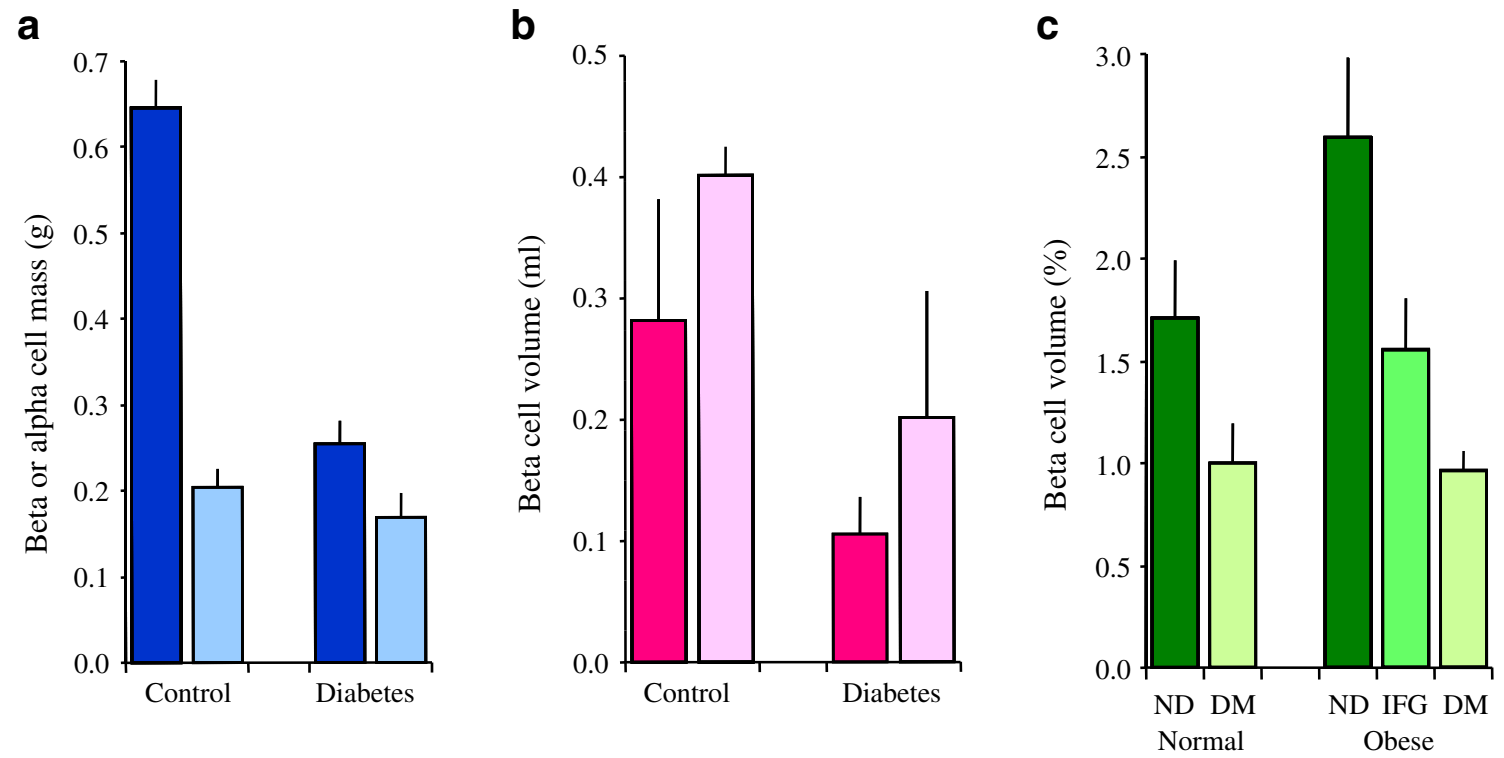

Fig. 2 Relationship of obesity and glucose tolerance with islet beta and alpha cell volume and mass based on autopsy assessments. a Beta cell mass (dark blue) is reduced in patients with type 2 diabetes $(n=25)$ compared with controls $(n=25)$, while alpha cell mass (pale blue) is not different. Patients with type 1 diabetes and those with amyloidosis were excluded. Data, mean $\pm \mathrm{SE}$, are reproduced with permission [4]. b Beta cell volume is increased in obese (pale pink) (four controls, six type 2 diabetes) compared with normal weight (dark pink) (seven controls, eight type 2 diabetes) patients. Diabetes is associated with reduced beta cell volume in both obese and normal weight patients. Data, mean $\pm \mathrm{SD}$, from [5]. c Beta cell volume is reduced in patients with type 2 diabetes (DM, pale green) (16 normal weight, 41 obese) compared with those who do not have diabetes (ND, dark green) (17 normal weight, 31 obese), regardless of whether participants are normal weight or obese. Patients with impaired fasting glucose (IFG, mid-green) ( $n=19$ obese) have reduced beta cell volume that is intermediate between no diabetes and diabetes. Data are mean \pm $\mathrm{SE}$ and reproduced with permission [6] 


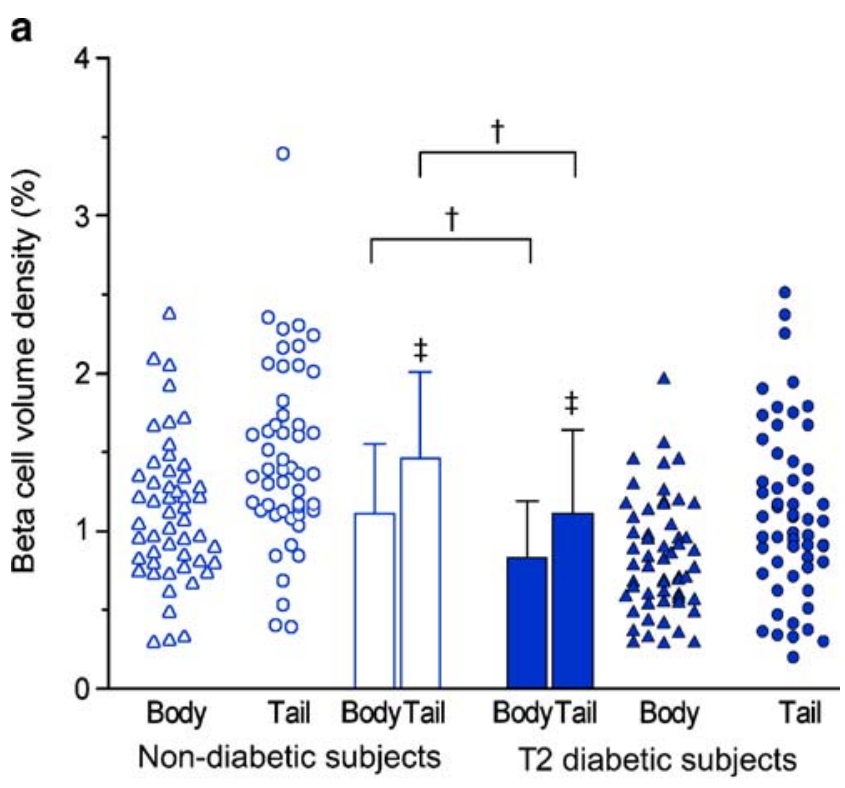

b

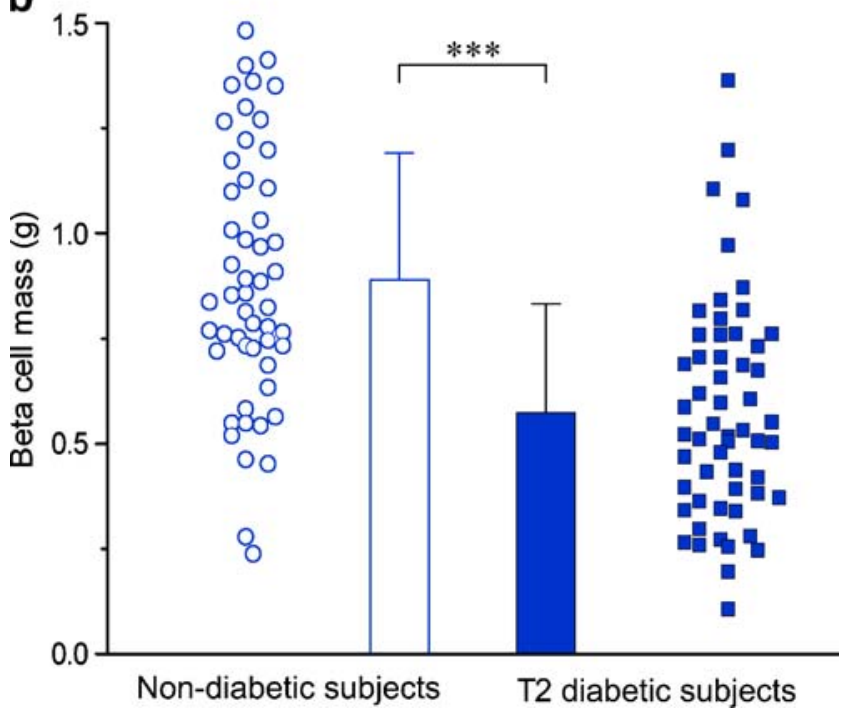

Fig. 3 Differences in beta cell volume and mass in 52 individuals without (white symbols and bars) and 57 with type 2 (T2) diabetes (blue symbols and bars). a The volume of beta cells varies markedly in non-diabetic and diabetic patients, with considerable overlap between the two groups. Despite this variability, beta cell volume is greater in the pancreatic tail than body in non-diabetic and diabetic patients. In patients with diabetes, beta cell volume is reduced, both in the pancreas body (by 25\%) and tail (by 24\%), compared with individuals without diabetes. ${ }^{\dagger} p<0.005$ for difference between diabetic and non-diabetic for both organ sections; ${ }^{\star} p<0.0001$ compared with the pancreas body. b Beta cell mass, determined on basis of volume density and pancreatic weight, is reduced by $35 \%$ in patients with type 2 diabetes $(* * * p<0.001)$. Data are mean $\pm \mathrm{SD}$ and reproduced with permission [12]

glucose tolerance were observed [13], while in patients who for medical reasons underwent a pancreatectomy of a similar magnitude, glucose tolerance either improved or deteriorated mildly [14]. The findings in these human studies are supported by work in rodents, dogs and monkeys. Studies in rodents, undertaken in large part by the Boston group, have highlighted the need to remove close to $90 \%$ of pancreatic tissue in healthy animals before hyperglycaemia can be demonstrated [15]. Similarly, two canine studies clearly showed that resection of 50\% [16] and $65 \%$ [17] of the pancreas did not result in diabetes. It is possible that the lack of a significant increase in fasting glucose in the studies of reduced beta cell mass produced by resection of pancreatic tissue are due to the simultaneous reduction of alpha cells, new beta cell formation or functional adaptation of the remaining beta cells. However, this has not been clearly demonstrated.

A $50 \%$ pancreatectomy in humans does not result in diabetes or compensatory regeneration of beta cells

Surgical reduction of islet mass reduces both alpha and beta cell number, and thus would be expected to reduce glucagon and insulin release. Prospective human data on this are rather limited, but the available information suggests that while fasting levels of glucagon and insulin are not different, the glucagon and insulin responses to arginine are probably decreased [13]. Thus, the glucagon: insulin ratio is not markedly altered, which is not the case in two non-human primate models where predominantly beta cells are lost. These two models of reduced beta cell mass, one chemical [18] and the other secondary to islet amyloid deposition [19], suggest that a reduction in the number of glucagon-producing cells is unlikely to explain lack of recurrence of hyperglycaemia. In the study where beta cells were destroyed with streptozotocin, normoglycaemia was maintained despite the fact that the number of insulin-secreting cells was clearly diminished [18]. In the other, an elevation in fasting glucose was only observed in the presence of beta and alpha cell secretory dysfunction and after islet amyloid deposition had reduced beta cell mass by over $50 \%$ [19]. Evidently, one has to look beyond changes in the number of alpha cells as the basis for the rather mild impairments in glucose tolerance and fasting glucose observed with simple beta cell mass reduction.

Could the lack of diabetes following beta cell mass reduction be explained by new beta cell formation? While caution is always necessary when extrapolating results from rodent models to humans, this applies even more so when considering the question above. That being said, some similarities do exist. There is clear evidence that the greatest turnover of beta cells occurs in the neonatal period in rodents and a similar event occurs in humans [20]. With obesity-associated insulin resistance, the volume of beta cells is increased $[5,6,12]$, which appears to be in part the result of increased secretory demand on the beta cell. 
Fig. 4 Plasma insulin concentrations before and following a $100 \mathrm{~g}$ glucose load in healthy control individuals (a) and patients known (b) to have early maturity-onset type 2 diabetes and those (c) in whom the duration of the diabetes was undetermined. The insulin response at $30 \mathrm{~min}$ was clearly diminished in individuals with recent-onset of hyperglycaemia. Reproduced with permission [26]

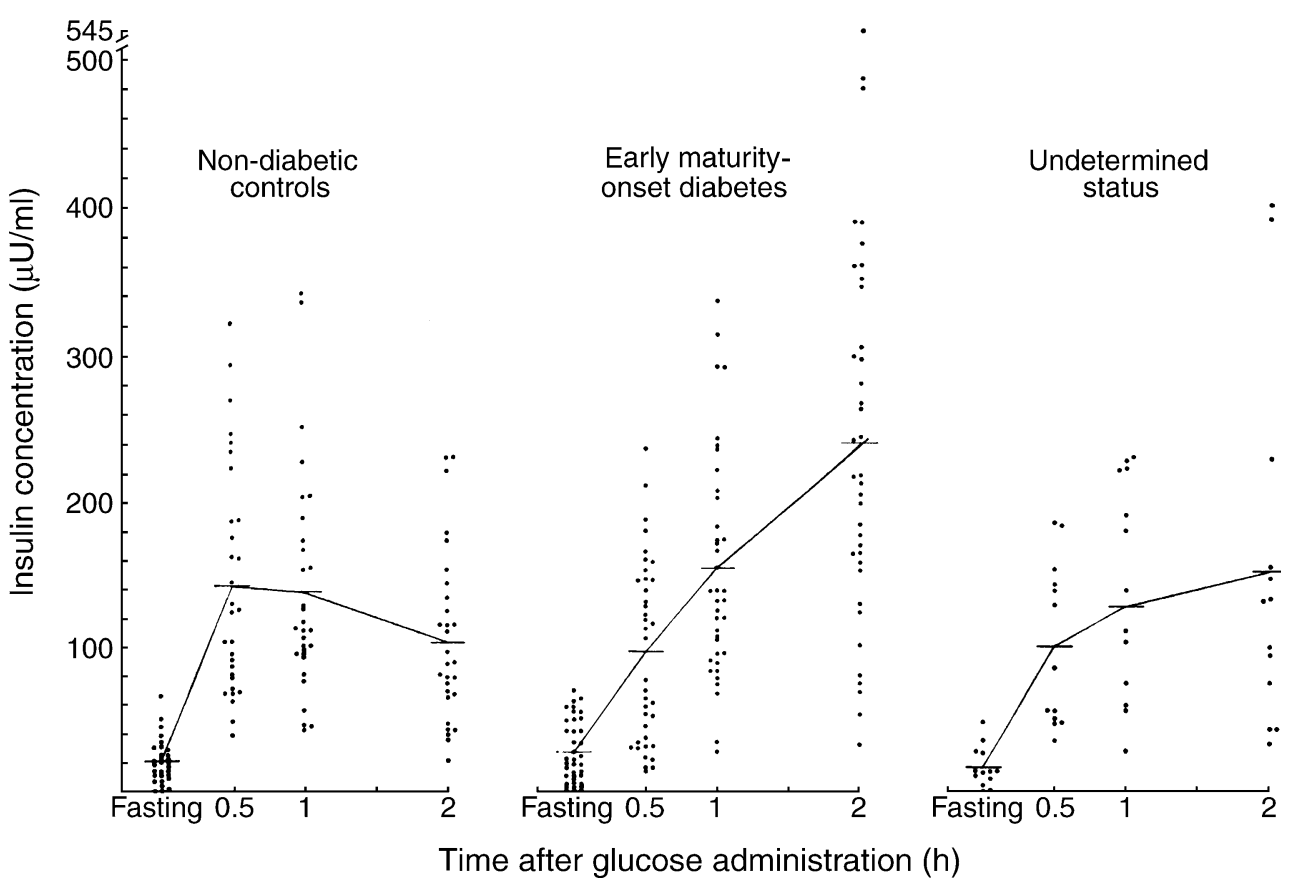

Pregnancy is also associated with insulin resistance and in rodents beta cell expansion occurs, followed post-partum by involution [21], a process also possibly occurring in humans [22]. However, later in life such expansion is less likely, as ageing is clearly associated with a decrease in the beta cell's ability to regenerate [23]. While in young rodents regeneration of beta cells may occur by replication of existing beta cells or neogenesis from exocrine ducts [24], the evidence for this occurring in humans and even in nonrodent animal models is minimal. In fact, a recent study underscored the difficulty of using the human pancreas to produce new beta cells [25]. In this work, examination of tissue obtained at consecutive partial pancreatectomies showed that the loss of beta cells did not result in compensatory regeneration, as there were no differences in the fractional beta cell area, the proportion of proliferating beta cells or numbers of duct cells expressing insulin [25]. A similar observation has been made in dogs following surgical reduction of beta cell mass. Several months after that procedure, the pancreatic remnant did not differ morphologically from the previously resected pancreas, including the number and size of islets, and the number of beta cells [16]. Thus, a compensatory response involving new beta cell formation seems to be a less likely mechanism for compensation of reduced beta cell volume, both in non-rodent models of reduced beta cell mass and in humans where beta cell mass is actually reduced.

Where does that leave us? A likely conclusion must be that a simple reduction in beta cell mass, often greater than that typically observed in humans with type 2 diabetes, fails to result in a clinically meaningful increase in glucose levels. From this it seems likely that when the beta cell is normal, the maintenance of glucose homeostasis following a reduction of beta cell mass is the consequence of an adaptive increase in beta cell function. This possibility is discussed in a subsequent section.

\section{Is beta cell function reduced in type 2 diabetes?}

Here again, the answer has been known for a substantial period of time, namely that there is no doubt that beta cell function is diminished. In fact, Yalow and Berson's development of the insulin radioimmunoassay half a century ago provided the first clear evidence of a defect in beta cell function [26] (Fig. 4). In that study, they showed that even in individuals with 'early maturity-onset diabetes', there was a defect in early insulin release following glucose ingestion. It has since been shown that this early insulin secretory defect following oral glucose is already well established in individuals with impaired glucose tolerance (IGT), irrespective of ethnicity [27, 28] (Fig. 5).

In humans with type 2 diabetes, first-phase insulin release is absent when beta cell volume is reduced by only $30-60 \%$

While this early insulin response to oral glucose is reduced in patients with diminished glucose tolerance and is further decreased in those with type 2 diabetes, insulin is still released (Figs 4, 5). In contrast, the acute insulin response following intravenous glucose injection is completely lacking in type 2 diabetes [29]. In fact, it has clearly been shown to decline 


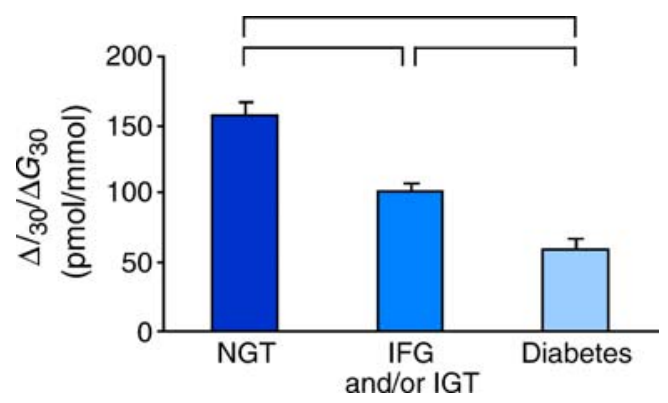

Fig. 5 Incremental early insulin response (insulinogenic index) measured $30 \mathrm{~min}$ after glucose ingestion $\left(\Delta I_{30} / \Delta G_{30}\right)$ in 240 participants with normal glucose tolerance (NGT), 191 with impaired fasting glucose (IFG)/IGT and 100 with diabetes. As glucose tolerance declined, beta cell function deteriorated. $p<0.001$ for all comparisons. Reproduced with permission [27]

with increasing fasting plasma glucose levels, commencing at a level of $5.0 \mathrm{mmol} / \mathrm{l}$ and frequently being absent when the concentration is below the diagnostic cut-off point for diabetes $[30,31]$ (Fig. 6). Thus, there is a clear dissimilarity in the responses to oral and intravenous glucose, with these distinctions demonstrating that the beta cell functional defect differentially affects the pathways that couple stimulus and secretion. Importantly, in contrast to the pathway responsible for the rapid release of insulin following intravenous glucose stimulation, coupling of signalling and secretion through pathways responsive to non-glucose secretagogues is not totally absent, even at glucose concentrations well above $7.0 \mathrm{mmol} / \mathrm{l}$, the level that defines human type 2 diabetes [32]. Interestingly, this is not simply a function of the in vivo situation, as analogous observations have been made in vitro using donor islets from healthy and type 2 diabetic individuals [33-35]. Thus perifusion or static incubation of islets from patients with type 2 diabetes demonstrated total loss of the response to glucose, with lesser reductions in the responses to potassium, arginine, glibenclamide and glucagon-like peptide-1 (GLP-1). The impact of this secretory defect has also been highlighted in studies in which transplantation of islets isolated from healthy humans into diabetic immunodeficient mice resulted in reversal of hyperglycaemia, while transplantation of equivalent numbers of islets from type 2 diabetic cadaveric donors did not [33]. However, a limitation of this report is that while similar numbers of islets were transplanted, the quantity of beta cells transplanted was not reported.

A number of abnormalities of continuous insulin release have also been described in individuals with type 2 diabetes and those at risk. The beta cell has an intrinsic pacemaker that generates pulses of insulin release approximately every $15 \mathrm{~min}[36,37]$. These rapid pulses occur against a background of slower, ultradian oscillations tightly coupled to natural oscillations in plasma glucose that have a periodicity of 80 to $150 \mathrm{~min}$ [38]. In type 2 diabetes and in high-risk states, these secretory patterns are altered. Thus, in individuals with a family history of type 2 diabetes, the rapid pulses are lost [37], while in patients with type 2 diabetes or IGT, the tight temporal oscillatory pattern between glucose and insulin is disturbed with oscillatory changes in insulin secretion lacking the normal periodicity [38]. Moreover, the normal beta cell can be entrained to oscillate in concert with exogenously produced glucose oscillations, with the amplitude of these oscillations increasing in proportion to the magnitude of change in plasma glucose [38]. In contrast, beta cells in individuals with IGT and type 2 diabetes are incapable of entraining and fail to increase insulin release appropriately in response to changes in plasma glucose [38].

In addition to these secretory changes, the biosynthesis of insulin has been shown to be abnormal in type 2 diabetes. Insulin production involves its proteolytic processing from a larger precursor proinsulin to the final products insulin and Cpeptide. This series of steps occurring within the beta cell is not $100 \%$ efficient, so that exocytosis of secretory granule content results in the release of small amounts of proinsulin and partially processed intermediates, along with C-peptide and insulin [39]. In type 2 diabetes, peptide processing is less efficient, leading to release of a greater proportion of proinsulin and resulting in disproportionate proinsulinaemia [39], which has been shown to be a marker for the subsequent development of diabetes in individuals at increased risk [40, 41].

Can these functional changes be simulated in individuals without beta cell mass reduction and thus lend credence to the concept that a simple functional lesion is all that is necessary for the development of type 2 diabetes? Based on observations with a number of different interventions, this seems unlikely. When beta cell granule exocytosis is reduced by administration of somatostatin, insulin release is clearly impaired, but at the same time this inhibitory peptide is not beta cell-selective so

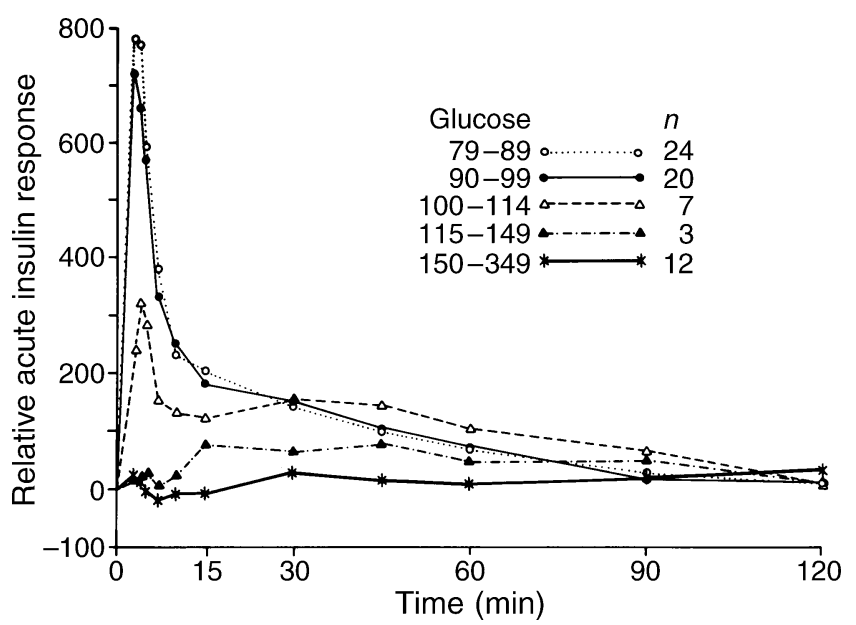

Fig. 6 Acute insulin response to intravenous glucose in participants grouped on basis of fasting glucose levels $(\mathrm{mg} / \mathrm{dl})$ as shown. As fasting glucose increases, the insulin response decreases. The response is absent when fasting glucose exceeds $115 \mathrm{mg} / \mathrm{dl}(6.4 \mathrm{mmol} / \mathrm{l})$. To convert $\mathrm{mg} / \mathrm{dl}$ to $\mathrm{mmol} / \mathrm{l}$, divide by 18 . Reproduced with permission [30] 
glucagon release from the alpha cell is also diminished. The result is only a relatively small rise in the fasting glucose concentration, even when glucagon is replaced [42]. When activity of the beta cell's potassium channel is inhibited with the anti-hypertensive diazoxide in order to impair glucosestimulated insulin secretion, the release of beta cell products is impaired, but again only a relatively mild change in glycaemia occurs [43]. Interestingly, while it is well recognised that glucocorticoids induce insulin resistance [44], they also have islet effects that result in a disproportionate increase in proinsulin release and increased glucagon output as observed in type 2 diabetes [45-48]; yet, in otherwise healthy individuals they do not induce major reductions in glucose tolerance. Finally, administration of catecholamines to mimic increased alpha adrenergic activity as a mechanism underlying beta cell dysfunction results in reduced insulin secretory responses, but again does not produce the abnormalities typically associated with the hyperglycaemia of type 2 diabetes [49]. Thus, it is not possible to intervene in humans with one of these approaches and reproduce the severity of the functional beta cell lesion of type 2 diabetes. However, it is unclear whether simultaneous abnormalities, e.g. of sympathetic tone and potassium channel activity, could result in the development of frank hyperglycaemia.

Where does that then leave us? It is clear that the defect in beta cell function in type 2 diabetes is global, occurring in the form of: (1) reductions in insulin secretory responses to orally ingested nutrients as well as to intravenous glucose and nonglucose secretagogues; (2) dampened pulsatile insulin release; and (3) impaired insulin biosynthesis. However, the magnitude of the functional abnormality differs according to the measure being examined. And as there is no easy way to chemically reproduce the beta cell abnormalities of type 2 diabetes, the lesion is likely, at a minimum, to be comprised of a number of changes in cellular function.

\section{Reduced beta cell mass or beta cell dysfunction-do they beget each other?}

It appears therefore that reductions in beta cell mass and beta cell function are present in individuals with type 2 diabetes. The critical question is: does one follow, or possibly even cause the other? As we cannot assess beta cell mass non-invasively, information in humans is nonexistent and it is difficult to know exactly what happens in the progression from normal glucose tolerance through IGT to type 2 diabetes. Thus, we have no choice but to turn to animal models or in vitro studies, both of which clearly have limitations, to extrapolate findings to the human disease process. Consideration of this important question must also include additional aspects of many of the studies discussed earlier.

First, let's consider the possibility that simple reductions in beta cell mass of the order observed in type 2 diabetes beget beta cell dysfunction. The available evidence in animal models suggests this simple mechanism is not likely to be operative. A $50 \%$ surgical reduction of pancreatic mass in dogs failed to produce changes in either fasting or arginine-stimulated insulin levels, fasting glucagon concentrations, peak insulin response to intravenous glucose or insulin sensitivity [16]. Given this lack of change, it is not surprising that the animals did not develop hyperglycaemia. This contrasts with type 2 diabetes and IGT, where reduced insulin responses, excessive glucagon release and insulin resistance exist to variable degrees $[1,2,48]$. To produce hyperglycaemia in these dogs with a reduced number of islets, it was necessary to infuse glucose continuously for 2 weeks to maintain the plasma glucose level above $13.9 \mathrm{mmol} / \mathrm{l}$ [16]. Similarly, in rats following a $60 \%$ pancreatectomy, glycaemia was not altered 6 weeks after surgery unless sucrose was introduced into the drinking

\begin{tabular}{ll} 
Islet function & \\
In type 2 diabetes & After partial pancreatectomy \\
\hline Absent first-phase insulin response to glucose & $\begin{array}{l}\text { Zero or minimal change in first-phase insulin } \\
\text { response to glucose }\end{array}$ \\
$\begin{array}{l}\text { Reduced insulin responses to non-glucose } \\
\text { secretagogues }\end{array}$ & $\begin{array}{l}\text { Reduced insulin responses to non-glucose } \\
\text { secretagogues }\end{array}$ \\
Loss of periodicity of pulsatile insulin release & Maintenance of periodicity of pulsatile insulin release \\
Insulin release not entrainable & Insulin release entrainable \\
Inappropriately increased glucagon responses & Reduced glucagon responses \\
Results in hyperglycaemia & Zero or minimal change in glycaemia
\end{tabular}


water for 3 weeks; even then the increase in non-fasting glucose was still $<1 \mathrm{mmol} / 1$ [50]. In Göttingen minipigs treated with streptozotocin and nicotinamide, a model of beta cell mass reduction in which alpha cells would not be anticipated to be reduced, mild hyperglycaemia developed, but derangements in the periodicity or entrainability of insulin release could not be reproduced, with only a simple reduction in the amplitude of the pulses being observed [51]. These findings contrast with the derangements of continuous insulin release observed in type 2 diabetic patients and those at increased risk [37, 52]. Consequently, as simple mass reduction does not seem to beget the functional abnormalities, it must be concluded that beta cell mass has been replenished and/or beta cell function improved.

The unlikelihood of beta cell mass replenishment occurring is suggested by the fact that not even a period of transient hyperglycaemia in the immediate days or weeks post-partial pancreatectomy was observed, even when up to two thirds of the pancreas had been removed [16, 17]. More importantly, as discussed and in keeping with this observation, at 6 months following removal of $50 \%$ of the pancreas the size and number of islets as well as the number of beta cells were not different from that in the portion of pancreas obtained at the time of resection [16]. Interestingly, this observation in dogs is consistent with the recent report of a lack of new beta cell formation following 50\% pancreatectomy in humans [25]. Thus, it would seem more likely that the normal beta cell adapts functionally to the loss of a large proportion of its fellow beta cells.

The innate capacity of the normal beta cell to prevent development of hyperglycaemia by enhancing its own function is suggested by studies in healthy animals that have undergone a surgical reduction in islet mass. Following a $65 \%$ pancreatectomy in dogs, which reduces beta cell mass to a greater degree than that typically found in human type 2 diabetes, beta cell sensitivity to glucose was enhanced [17]. This adaptive change means that at physiological glucose concentrations each beta cell releases insulin more efficiently, thereby maintaining euglycaemia. Observations compatible with such an enhancement of beta cell sensitivity to glucose have also been made in rodent models of reduced beta cell mass [53]. Thus, it would appear that a dysfunctional beta cell might be unable to adapt to a reduction in beta cell mass, resulting ultimately in the development of hyperglycaemia.

More recent work using genetically modified rodents strongly supports the notion that reduced beta cell mass alone is insufficient and that beta cell dysfunction must preexist, if mass reduction is to result in hyperglycaemia. In a mouse lacking the critical transcription factor FoxM1, proliferation of existing beta cells cannot occur; yet, despite this inability to form new beta cells, a $60 \%$ pancreatectomy does not result in changed glucose tolerance [54]. On the other hand, a 70\% pancreatectomy in GLP-1 receptor-null mice, which fail to release insulin in response to GLP-1 [55], resulted in the development of marked hyperglycaemia [56]. Thus, we conclude that when the remaining beta cells are functionally normal, a simple reduction in mass alone does not produce beta cell dysfunction; however, when the remaining beta cells are dysfunctional, the additional insult of a reduction in beta cell mass results in hyperglycaemia.

Could beta cell dysfunction be the basis for a reduction in beta cell mass? Here again the inability to monitor possible changes in beta cell mass in situ has required the use of in vitro systems or animal models in which pancreatic material is typically only accessible post mortem. It is clear from in vitro work that elevations in glucose and fatty acids, either alone or together, are associated with the induction of beta cell dysfunction and the loss of beta cells by apoptosis [57]. However, these changes are not easily repeated in vivo.

Glucose-induced changes in beta cell morphology that could be considered indicative of reduced beta cell mass have been observed. In dogs, following 2 months of sustained hyperglycaemia, which was only attainable after 2 weeks of continuous glucose administration on a background of reduced beta cell mass, the number and size of islets was found to be profoundly reduced, with marked depletion of insulin stores [16]. In rats, by contrast, $96 \mathrm{~h}$ of hyperglycaemia produced by continuous infusion of glucose was associated with an increase in beta cell mass through hypertrophy and replication, probably averting further hyperglycaemia [58]. These findings contrast with those in hyperglycaemic humans, in whom compensatory generation of new beta cells did not occur $[5,6,12]$. While these glucose-infused animal models are of interest, their relevance as a primary mechanism to explain human type 2 diabetes is questionable, since the human condition does not typically transition rapidly from normal glucose tolerance through IGT to marked hyperglycaemia, but instead progresses over years.

While classically thought of in terms of peptide release, beta cell dysfunction could lead to beta cell loss through a mechanism or mechanisms unrelated solely to exocytosis. Insulin is not the only unique peptide synthesised by the beta cell, for the cell also produces and co-releases islet amyloid polypeptide (IAPP; or amylin) in parallel with insulin [59]. Whereas the physiology of IAPP is poorly understood, its association with the loss of beta cell mass in type 2 diabetes is clearer. Normally, this amyloidogenic peptide does not aggregate to form amyloid fibrils, whereas in type 2 diabetes it does so, a process during which beta cell death and mass loss are likely to ensue [60]. It is not clear in human type 2 diabetes what beta cell environment is permissive for IAPP 
aggregation to occur, but it has been suggested that impaired processing of the larger precursor proIAPP to native IAPP may be an important contributor [61, 62]. Further work is needed to determine the basis for IAPP aggregation and may throw light on whether this represents an instance of beta cell dysfunction initiating the process of beta cell loss.

The question, therefore, of whether reduced beta cell mass could beget beta cell dysfunction or vice-versa is complex. Of the two possibilities, the latter seems more likely on the basis of current data. However, the evidence is far from definitive and more work is clearly required.

\section{So is the beta cell lesion of type 2 diabetes simply 'decreased functional beta cell mass' or is it 'decreased beta cell mass and function'?}

The former and rather interesting description of the beta cell lesion of type 2 diabetes has come about in recent years. Its basis and meaning appear to us somewhat mysterious and perhaps even misleading.

The meaning of the term 'functional beta cell mass' appears somewhat mysterious and even misleading

If one accepts the premise that beta cell mass is decreased in type 2 diabetes, does this term then mean that the reason hyperglycaemia develops is because normally functioning beta cells have been lost and only dysfunctional cells remain? Or alternatively, are the changes simply a question of beta cell mass reduction resulting in a critical reduction in the volume of normally functioning beta cells? Or, on the other hand, could the changes represent a loss of beta cells, which then leads through 'stress' to the loss of beta cell function? Based on the evidence we have presented, the answer is truly unclear. The inadequacy of the term 'decreased functional beta cell mass', moreover, is clearly underscored by the fact that, in the presence of a sizeable number of beta cells containing plenty of insulin, the first-phase response to intravenous glucose can be totally absent, whereas other responses such as that to intravenous GLP-1 or oral glucose are still present. We therefore feel the term is a misnomer and consideration should be given to striking it from discussion.

What would we propose as a better descriptor? We believe that the beta cell lesion of type 2 diabetes is multifactorial. It is likely to be genetically determined and influenced by the environment, both intra-uterine and from birth throughout life. The genetic underpinning may be twofold, with genetically determined reductions in both beta cell secretory function and beta cell mass coexisting (Fig. 7a). Alternatively, although in our view less likely, the beta cell lesion may result from a genetic susceptibility that simultaneously affects both mass and function (Fig. 7b). Finally, we cannot rule out the possibility that, against a background of a genetic abnormality, a dysfunctional beta cell may lie upstream of a mass lesion and that the coexistence of a 'toxic' environment could further elaborate this beta cell abnormality, leading to the loss of beta cells (Fig. 7c). Therefore, we feel that it is unwise to combine the processes of loss of beta cell mass and loss of beta cell function into a single entity. To us, they represent separate and yet critical interdependent processes and should be seen that way. We propose that as the complex beta cell lesion of type 2 diabetes is the result of 'decreased beta cell mass and function', it should be considered and termed that way. An understanding of the basis for the failure of these two components holds part of the key to the pathogenesis of the islet lesion of type 2 diabetes, and ultimately to better approaches to its therapy. a

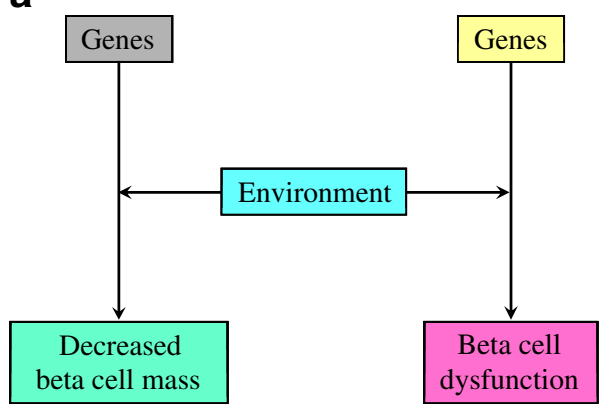

b

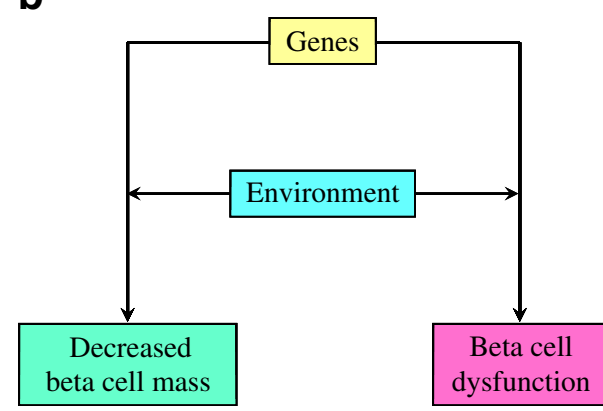

c

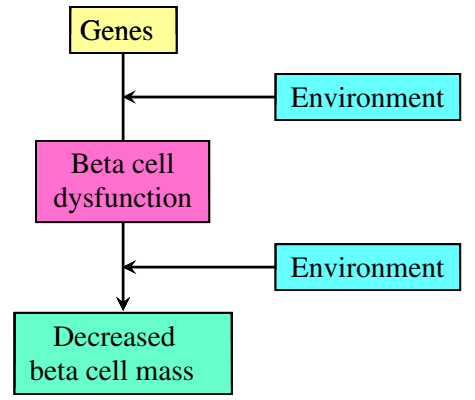

Fig. 7 Possible pathways for development of the reduced beta cell mass and beta cell dysfunction observed in type 2 diabetes. a Genetic defects combined with environmental changes determine reductions in beta cell function and mass. b A genetic defect in combination with environmental changes simultaneously affects mass and function. c
The interaction of genetic susceptibility with environmental factors results in beta cell dysfunction, which in turn leads to a loss of beta cells. The effect of these combinations of changes is the development of hyperglycaemia 
Acknowledgements This work was supported in part by the Department of Veterans Affairs, NIH grants DK-075998 and DK-074404, and a Juvenile Diabetes Research Foundation Fellowship to S. Zraika.

Duality of interest The authors declare that they there is no duality of interest associated with this manuscript.

\section{References}

1. Reaven GM (1988) Role of insulin resistance in human disease. Diabetes 37:1595-1607

2. Kahn SE (2003) The relative contributions of insulin resistance and beta-cell dysfunction to the pathophysiology of type 2 diabetes. Diabetologia 46:3-19

3. Opie E (1901) The relation of diabetes mellitus to lesions of the pancreas. Hyaline degeneration of the islets of Langerhans. J Exp Med 5:527-540

4. Maclean N, Ogilvie RF (1955) Quantitative estimation of the pancreatic islet tissue in diabetic subjects. Diabetes 4:367-376

5. Kloppel G, Lohr M, Habich K, Oberholzer M, Heitz PU (1985) Islet pathology and the pathogenesis of type 1 and type 2 diabetes mellitus revisited. Surv Synth Pathol Res 4:110-125

6. Butler AE, Janson J, Bonner-Weir S, Ritzel R, Rizza RA, Butler PC (2003) B-cell deficit and increased B-cell apoptosis in humans with type 2 diabetes. Diabetes 52:102-110

7. Clark A, Wells CA, Buley ID et al (1988) Islet amyloid, increased A-cells, reduced B cells and exocrine fibrosis: quantitative changes in the pancreas in type 2 diabetes. Diabetes Res 9:151159

8. Rahier J, Goebbels RM, Henquin JC (1983) Cellular composition of the human diabetic pancreas. Diabetologia 24:366-371

9. Saito K, Yaginuma N, Takahashi T (1979) Differential volumetry of $\mathrm{A}, \mathrm{B}$, and $\mathrm{D}$ cells in the pancreatic islets of diabetic and nondiabetic subjects. Tohoku J Exp Med 129:273-283

10. Sakuraba H, Mizukami H, Yagihashi N, Wada R, Hanyu C, Yagihashi S (2002) Reduced beta-cell mass and expression of oxidative stress-related DNA damage in the islet of Japanese Type II diabetic patients. Diabetologia 45:85-96

11. Yoon KH, Ko SH, Cho JH et al (2003) Selective $\beta$-cell loss and $\alpha$ cell expansion in patients with type 2 diabetes mellitus in Korea. J Clin Endocrinol Metab 88:2300-2308

12. Rahier J, Guiot Y, Goebbels RM, Sempoux C, Henquin JC (2008) Pancreatic B-cell mass in European subjects with type 2 diabetes. Diabetes Obes Metab 10(Suppl 4):32-42

13. Seaquist ER, Robertson RP (1992) Effects of hemipancreatectomy on pancreatic alpha and beta cell function in healthy human donors. J Clin Invest 89:1761-1766

14. Menge BA, Schrader H, Breuer TG et al (2009) Metabolic consequences of a $50 \%$ partial pancreatectomy in humans. Diabetologia 52:306-317

15. Bonner-Weir S, Trent DF, Weir GC (1983) Partial pancreatectomy in the rat and subsequent defect in glucose-induced insulin release. J Clin Invest 71:1544-1553

16. Imamura T, Koffler M, Helderman JH et al (1988) Severe diabetes induced in subtotally depancreatized dogs by sustained hyperglycemia. Diabetes 37:600-609

17. Ward WK, Wallum BJ, Beard JC, Taborsky GJ Jr, Porte D Jr (1988) Reduction of glycemic potentiation: a sensitive indicator of ß-cell loss in partially pancreatectomized dogs. Diabetes 37:723729

18. McCulloch DK, Raghu PK, Johnston C et al (1988) Defects in Bcell function and insulin sensitivity in normoglycemic streptozocintreated baboons: a model of preclinical insulin-dependent diabetes. J Clin Endocrinol Metab 67:785-792
19. Howard CF Jr (1986) Longitudinal studies on the development of diabetes in individual Macaca nigra. Diabetologia 29:301-306

20. Kassem SA, Ariel I, Thornton PS, Scheimberg I, Glaser B (2000) Bcell proliferation and apoptosis in the developing normal human pancreas and in hyperinsulinism of infancy. Diabetes 49:1325-1333

21. Sorenson RL, Brelje TC (1997) Adaptation of islets of Langerhans to pregnancy: beta-cell growth, enhanced insulin secretion and the role of lactogenic hormones. Horm Metab Res 29:301-307

22. Van Assche FA, Aerts L, De Prins F (1978) A morphological study of the endocrine pancreas in human pregnancy. Br J Obstet Gynaecol 85:818-820

23. Teta M, Long SY, Wartschow LM, Rankin MM, Kushner JA (2005) Very slow turnover of beta-cells in aged adult mice. Diabetes 54:2557-2567

24. Bonner-Weir S, Baxter LA, Schuppin GT, Smith FE (1993) A second pathway for regeneration of adult exocrine and endocrine pancreas. A possible recapitulation of embryonic development. Diabetes 42:1715-1220

25. Menge BA, Tannapfel A, Belyaev O et al (2008) Partial pancreatectomy in adult humans does not provoke $\beta$-cell regeneration. Diabetes 57:142-149

26. Yalow RS, Berson SA (1960) Immunoassay of endogenous plasma insulin in man. J Clin Invest 39:1157-1175

27. Jensen CC, Cnop M, Hull RL, Fujimoto WY, Kahn SE, American Diabetes Association GENNID Study Group (2002) ß-cell function is the major determinant of oral glucose tolerance in four ethnic groups in the United States. Diabetes 51:2170-2178

28. Mitrakou A, Kelley D, Mokan M et al (1992) Role of reduced suppression of glucose production and diminished early insulin release in impaired glucose tolerance. N Engl J Med 326:22-29

29. Pfeifer MA, Halter JB, Porte D Jr (1981) Insulin secretion in diabetes mellitus. Am J Med 70:579-588

30. Brunzell JD, Robertson RP, Lerner RL et al (1976) Relationships between fasting plasma glucose levels and insulin secretion during intravenous glucose tolerance tests. J Clin Endocrinol Metab 42:222-229

31. Godsland IF, Jeffs JA, Johnston DG (2004) Loss of beta cell function as fasting glucose increases in the non-diabetic range. Diabetologia 47:1157-1166

32. Ward WK, Bolgiano DC, McKnight B, Halter JB, Porte D Jr (1984) Diminished B cell secretory capacity in patients with noninsulin-dependent diabetes mellitus. J Clin Invest 74:13181328

33. Deng S, Vatamaniuk M, Huang X et al (2004) Structural and functional abnormalities in the islets isolated from type 2 diabetic subjects. Diabetes 53:624-632

34. Del Guerra S, Lupi R, Marselli L et al (2005) Functional and molecular defects of pancreatic islets in human type 2 diabetes. Diabetes 54:727-735

35. Ostenson CG, Gaisano H, Sheu L, Tibell A, Bartfai T (2006) Impaired gene and protein expression of exocytotic soluble Nethylmaleimide attachment protein receptor complex proteins in pancreatic islets of type 2 diabetic patients. Diabetes 55:435-440

36. Bergstrom RW, Fujimoto WY, Teller DC, De Haen C (1989) Oscillatory insulin secretion in perifused isolated rat islets. Am J Physiol 257:E479-E485

37. O'Rahilly S, Turner RC, Matthews DR (1988) Impaired pulsatile secretion of insulin in relatives of patients with non-insulindependent diabetes. N Engl J Med 318:1225-1230

38. O’Meara NM, Sturis J, Van Cauter E, Polonsky KS (1993) Lack of control by glucose of ultradian insulin secretory oscillations in impaired glucose tolerance and in non-insulin-dependent diabetes mellitus. J Clin Invest 92:262-271

39. Kahn SE, Halban PA (1997) Release of incompletely processed proinsulin is the cause of the disproportionate proinsulinemia of NIDDM. Diabetes 46:1725-1732 
40. Kahn SE, Leonetti DL, Prigeon RL, Bergstrom RW, Fujimoto WY (1995) Proinsulin as a marker for the development of NIDDM in Japanese-American men. Diabetes 44:173-179

41. Mykkanen L, Haffner SM, Kuusisto J, Pyorala K, Hales CN, Laakso M (1995) Serum proinsulin levels are disproportionately increased in elderly prediabetic subjects. Diabetologia 38:11761182

42. Ward WK, Halter JB, Best JD, Beard JC, Porte D Jr (1983) Hyperglycemia and $\beta$-cell adaptation during prolonged somatostatin infusion with glucagon replacement in man. Diabetes 32:943-947

43. Raju B, Cryer PE (2005) Mechanism, temporal patterns, and magnitudes of the metabolic responses to the KATP channel agonist diazoxide. Am J Physiol Endocrinol Metab 288:E80-E85

44. Rizza RA, Mandarino LJ, Gerich JE (1982) Cortisol-induced insulin resistance in man: impaired suppression of glucose production and stimulation of glucose utilization due to a postreceptor detect of insulin action. J Clin Endocrinol Metab 54:131-138

45. Ward WK, LaCava EC, Paquette TL, Beard JC, Wallum BJ, Porte D Jr (1987) Disproportionate elevation of immunoreactive proinsulin in type 2 (non-insulin-dependent) diabetes mellitus and experimental insulin resistance. Diabetologia 30:698-702

46. Kalhan SC, Adam PAJ (1975) Inhibitory effect of prednisone on insulin secretion in man: model for duplication of blood glucose concentration. J Clin Endocrinol Metab 41:600-610

47. Marco J, Calle C, Roman D, Diaz-Fierros M, Villaneuva ML (1973) Hyperglucagonism induced by glucocorticoid treatment in man. N Engl J Med 288:128-131

48. Raskin P, Aydin I, Yamamoto T, Unger RH (1978) Abnormal alpha cell function in human diabetes: the response to oral protein. Am J Med 64:988-997

49. Robertson RP, Halter JB, Porte D Jr (1976) A role for alphaadrenergic receptors in abnormal insulin secretion in diabetes mellitus. J Clin Invest 57:791-795

50. Leahy JL, Bonner-Weir S, Weir GC (1988) Minimal chronic hyperglycemia is a critical determinant of impaired insulin secretion after an incomplete pancreatectomy. J Clin Invest 81:1407-1414
51. Larsen MO, Gotfredsen CF, Wilken M, Carr RD, Porksen N, Rolin B (2003) Loss of beta-cell mass leads to a reduction of pulse mass with normal periodicity, regularity and entrainment of pulsatile insulin secretion in Göttingen minipigs. Diabetologia 46:195-202

52. Porksen N (2002) Early changes in beta-cell function and insulin pulsatility as predictors for type 2 diabetes. Diabetes Nutr Metab 15(Suppl):9-14

53. Leahy JL, Bonner-Weir S, Weir GC (1984) Abnormal glucose regulation of insulin secretion in models of reduced B cell mass. Diabetes 33:667-673

54. Ackermann Misfeldt A, Costa RH, Gannon M (2008) Beta-cell proliferation, but not neogenesis, following $60 \%$ partial pancreatectomy is impaired in the absence of FoxM1. Diabetes 57:3069-3077

55. Pederson RA, Satkunarajah M, McIntosh CH et al (1998) Enhanced glucose-dependent insulinotropic polypeptide secretion and insulinotropic action in glucagon-like peptide 1 receptor -/mice. Diabetes 47:1046-1052

56. De Leon DD, Deng S, Madani R, Ahima RS, Drucker DJ, Stoffers DA (2003) Role of endogenous glucagon-like peptide-1 in islet regeneration after partial pancreatectomy. Diabetes 52:365-371

57. Poitout V, Robertson RP (2008) Glucolipotoxicity: fuel excess and B-cell dysfunction. Endocr Rev 29:351-366

58. Bonner-Weir S, Deery D, Leahy JL, Weir GC (1989) Compensatory growth of pancreatic $\beta$-cells in adult rats after short-term glucose infusion. Diabetes 38:49-53

59. Kahn SE, Verchere CB, Andrikopoulos S et al (1998) Reduced amylin release is a characteristic of impaired glucose tolerance and type 2 diabetes in Japanese Americans. Diabetes 47:640-645

60. Hull RL, Westermark GT, Westermark P, Kahn SE (2004) Islet amyloid: a critical entity in the pathogenesis of type 2 diabetes. $\mathrm{J}$ Clin Endocrinol Metab 89:3629-3643

61. Porte D Jr, Kahn SE (1989) Hyperproinsulinemia and amyloid in NIDDM: clues to etiology of islet $\beta$-cell dysfunction? Diabetes 38:1333-1336

62. Marzban L, Rhodes CJ, Steiner DF, Haataja L, Halban PA, Verchere CB (2006) Impaired NH2-terminal processing of human proislet amyloid polypeptide by the prohormone convertase PC2 leads to amyloid formation and cell death. Diabetes 55:2192-2201 